S E S S Ã O

25 de maio de 2021

\title{
Sessão da Saudade em Memória do \\ Acad. Carlos Américo Paiva Gonçalves Filho
}

“Náo Perdemos Paiva Gonçalves Filho, ELE INGRESSOU NA IMORTALIDADE"

"Um homem muito sentido pela ausência, mas muito lembrado pela presença, eu diria na História, não apenas da Academia Nacional de Medicina (ANM), mas da Oftalmologia brasileira.", proferiu o presidente da ANM, professor Rubens Belfort Jr, na abertura da Sessão Saudade, realizada em 25 de maio, que homenageou o acadêmico Carlos Américo Paiva Gonçalves Filho, falecido em 2 de janeiro de 2021.

$\mathrm{Na}$ sequência, outros colegas acadêmicos discursaram, relembrando a trajetória profissional impecável de Paiva Gonçalves Filho, como professor dedicado e apaixonado pela Escola de Medicina Souza Marques, entre outros locais que lecionava. Foi lembrado também pelo excelente trabalho frente ao serviço de oftalmologia na Santa Casa de Misericórdia, no Rio de Janeiro, onde conviveu diretamente com o acadêmico Sérgio Novis que dedicou algumas palavras ao amigo.

- Tivemos muitos anos convivendo na nossa querida Santa Casa, onde a primeira enfermaria de serviço oftalmológico foi chefiada pelo pai dele, ele e agora seu neto. Me surpreende, a uma hora dessa, não termos só saudade, a verdade é que - meu pai me disse isso - a amizade é o melhor parentesco e mais: "não se vai de todo embora, quem nos vivos vive". Refletindo, percebi que quem dá a imortalidade são os admiradores do imortal. $\mathrm{O}$ indivíduo se torna imortal por aqueles que o seguem, o citam. A memória, que é um dos dons mais abençoados que temos, tem esse

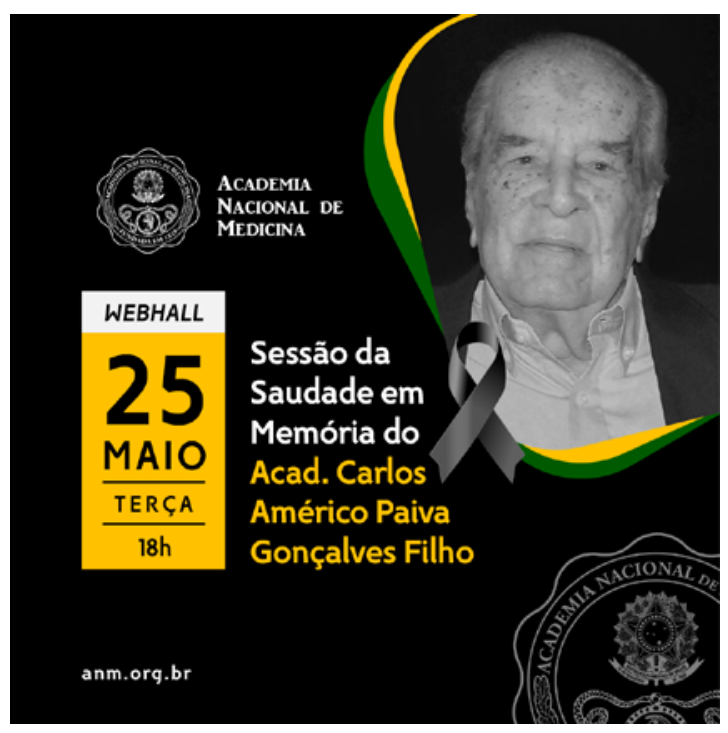

Imagem: divulgaçấo 
poder de trazer de novo à vida, aqueles que já se foram. Então, o começo de janeiro não foi o momento que nós perdemos o Paiva Gonçalves, foi o momento que ele ingressou na imortalidade e, cabe a nós, não permitir que ele saia dessa posição.

$\mathrm{O}$ acadêmico e oftalmologista Oswaldo Moura Brasil relembrou a competência, cordialidade e humanismo caraterístico dos atendimentos do amigo Paiva Gonçalves, com quem conviveu mais de 50 anos. Citou suas premiações e contribuição relevante com trabalhos, participações em importantes congressos nacionais e internacionais e inúmeras palestras e aulas ministradas. Mas também revelou o lado carinhoso e zeloso com a família e amigos.

- A imortalidade acadêmica está relacionada ao que se foi, ao que se é e ao legado que se deixa. $\mathrm{O}$ acadêmico Paiva Gonçalves Filho, certamente, é um imortal.

Representando os ex-presidentes da Academia Nacional de Medicina, o acadêmico Jorge Alberto Costa e Silva, destacou Paiva Gonçalves como um exemplo de vida.

- Ele teve uma carreira brilhante. $\mathrm{O}$ que fez é um exemplo do sentido da vida. Estamos celebrando a vida no sentido mais amplo que é a memória carregada de sentimentos de amor e saudade. Isso é sentir a presença do outro, mesmo que longe.

Seu filho, Paiva Gonçalves Neto também proferiu algumas palavras, lembrando um ensinamento que carrega até hoje. "Posso tirar três coisas que meu pai sempre falou para

que fosse um bom médico: gostar de gente, estudar muito e ser humilde."

Já no encerramento, o presidente da ANM, professor Belfort, revelou sua história pessoal com as três geraçóes da família Paiva Gonçalves. Segundo ele, foi por meio do renomado Paiva Gonçalves que passou a receber notícias da Academia Nacional de Medicina, abrindo portas para o que era a cultura da instituição.

Rubens Belfort contou que foi por influência dele que, em algum dia do passado, resolveu ingressar na ANM e, graças a forte indicação do primeiro Paiva Gonçalves, afirmando seu sentimento de gratidão. "Ele foi um grande companheiro e, apesar da diferença de idade, sempre se colocava próximo e procurava entender meu jeito para se comunicar melhor comigo. Hoje, estamos indo muito além do protocolo, estamos abrindo nossos corações", disse em tom emocionado.

A íntegra da Sessão Saudade pode ser conferida no canal do YouTube https:// www.anm.org.br/sessao-da-saudade-emmemoria-do-acad-carlos-americo-paivagoncalves-filho-25-de-maio-de-2021/

Para assistir na integra aos vídeos desse Simpósio, basta abrir esse QR Code abaixo em seu celular ou tablet.

Sessão

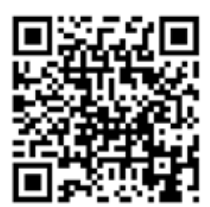

Todas as Sessóes

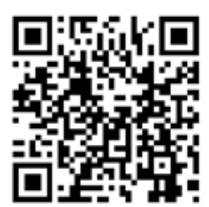




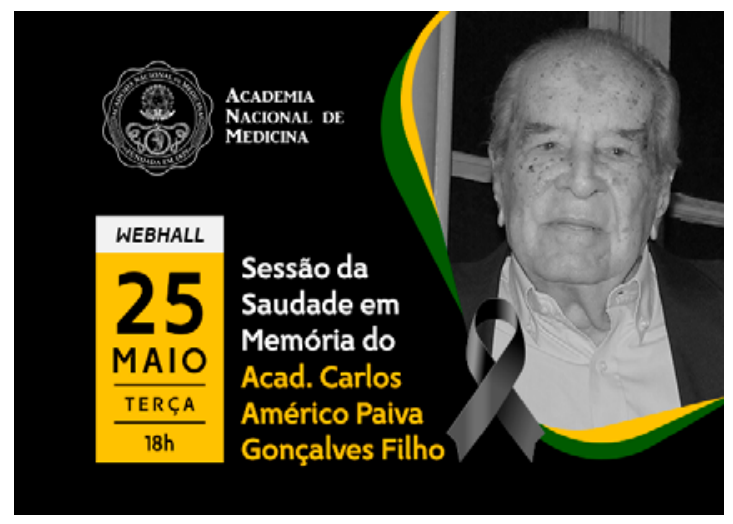

Coordenaçäo: Diretoria ANM

$18 \mathrm{~h}$ Abertura

Presidente da Academia Nacional de Medicina, Acad. Rubens Belfort Jr.

Secretário Geral ANM, Acad. Carlos Eduardo Brandão
18h05 Em memória do Acad. Carlos Américo Paiva Gonçalves Filho Acad. Sérgio Novis
Acad. Jorge Alberto Costa e Silva
Acad. Oswaldo Moura Brasil
18h35 Abertura da palavra aos Acadêmicos e Convidados
Ex-Presidentes ANM
Convidados
Acadèmicos

\begin{tabular}{ll}
$18 \mathrm{~h} 50$ & Abertura da palavra aos familiares \\
\hline $20 \mathrm{~h}$ & Encerramento
\end{tabular}

\section{anm.org.br}

